\title{
AN ANALYSIS ON THE IMPLEMENTATION FOR COVID-19 VACCINE PROGRAM IN BOGOR CITY INDONESIA
}

\author{
Dessy Yuliarty \\ Faculty of Public Health, Muhammadiyah University of Jakarta \\ E-Mail: dessyaffandiv5@gmail.com
}

\begin{abstract}
The covid-19 outbreak has been impacted the foundation of human life that encompasses social, economic, political, and environmental including in Bogor city. Bogor government efforts have been undertaken to ameliorate this condition but yet no significant improvement to stop this pandemic. However, the Covid-19 vaccine program initiated by the government has given a positive impact to reduce the positivity rate in Bogor city. Although there are some issues this vaccine program continues to sustain amid uncertainties. This paper, therefore, aims to explore some implementation of the Covid-19 vaccine program in Bogor city and analyze its impact on the positivity rate of Covid-19. To meet this objective, this paper employs a qualitative approach through literature review to unveil the real implementation of the vaccine program in Bogor city. This paper finds that the vaccine program of Covid-19 has not been able to stop completely the Covid-19 outbreak. There are some problems such as literacy and perception of the public towards this vaccine program, the availability of human resources to support this program, and lastly lack of sufficient funds to succeed this vaccine program. This paper implies that hospitals, clinics, and other health institutions must be supported by proper regulation to enhance vaccine programs particularly to provide qualified human resources since the positivity rate tend to increase and sufficient fund in the form of incentives for medical employees.
\end{abstract}

Keywords: Vaccine, Covid-19, Strategy, Bogor City 


\section{INTRODUCTION}

One of the Indonesian government's efforts to combat the Covid 19 outbreak is by vaccinating all Indonesians. The government started the COVID-19 Vaccination Program on January 13,2021 . The program is divided into four phases with health workers receiving the first batch of vaccines, followed by public servants, the senior citizen, and then followed by other community members. As of April 28, 2021, there were 12,112,888 people have been vaccinated against COVID-19 or 131,854 more than the previous day. Meanwhile, 7,374,458 people received their second vaccination or 195,690 more than the previous day.

However, as the number of Covid-19 cases in Indonesia continues to exceed more than one million, the government's neglect of other public health measures supporting aggressive mandatory vaccination efforts shows a clear disregard for its human rights obligations.

The Chinese-made Sinovac vaccine, the only one currently available in Indonesia, has been met with considerable skepticism by some parts of the public. Efficacy data vary widely, with results from the largest clinical trial in Brazil finding that while effective in preventing serious disease, it is only $50.65 \%$ effective in preventing infection. This figure is far below the figure for alternative vaccines now distributed in other countries.

Experts have also raised concerns about the limited safety and testing information being disclosed about the Chinese vaccine. The skepticism among the public is further strengthened by the spread of misinformation on social media.

Distrust of the Covid-19 vaccine seems so rife that on February 9, President Jokowi issued a presidential regulation stating that anyone who refuses vaccination can be denied to receive social assistance programs or other government services, or even be fined.

Vaccination must be of particular concern considering that Indonesia has a history of using coercion for the sake of public health. During the authoritarian period of the New Order, heavy social and administrative pressure was used to pressure women to join government family planning programs in certain regions of Indonesia.

Meanwhile, about the Covid-19 vaccination program in Bogor City, according to the Health Office funds, the Bogor City Government received 69,570 doses of vaccine stored in the pharmacy warehouse of the Bogor City Health Office. This vaccine was started for health workers as the first stage followed by the second stage for public servants, vulnerable groups (senior citizens), and the general public.

The achievement of the Public Service Vaccine program in Bogor City itself for the period March 30 - April 102021 targeted 12,431 people, but only 7,458 people had been 
Volume I Tahun 2021 November 2021
E-ISSN: 2808-5361

http://e-journal.fkmumj.ac.id/
Proceeding The First

Muhammadiyah

Internasional- Public Health

and Medicine Conference

vaccinated. Meanwhile, the senior citizen targeted recorded at 19,600 people, but only 8,503 of them were successfully vaccinated. The following is data on the vaccination program for public servants and the senior citizen in Bogor City:

\begin{tabular}{|c|c|c|c|c|c|c|c|c|c|c|c|c|c|c|c|}
\hline \multirow{3}{*}{ NAMA FASYANKES } & \multirow{3}{*}{$\begin{array}{c}\text { TOTAL } \\
\text { SASARAN } \\
\text { LANSIA }\end{array}$} & \multirow{3}{*}{$\begin{array}{c}\text { TOTAL } \\
\text { SASARAN } \\
\text { PETUGAS } \\
\text { PUBLIK }\end{array}$} & \multicolumn{13}{|c|}{ SASARAN LANSIA } \\
\hline & & & 30-Mar & 31 Maret & 01-Apr & 03-Apr & \multirow[t]{2}{*}{ 04-Apr } & 05-Apr & 06-Apr & 07-Apr & 08-Apr & 09-Apr & 10-Apr & \multicolumn{2}{|c|}{$\begin{array}{c}\text { Pencapaian Dosis } \\
1\end{array}$} \\
\hline & & & Dosis1 & Dosis1 & Dosis1 & Dosis 1 & & Dosis1 & Dosis 1 & Dosis 1 & Dosis 1 & Dosis 1 & Dosis 1 & Total & $\%$ \\
\hline PKM PULO ARMYN & 1000 & & 0 & 19 & 36 & & HARा & 32 & 44 & 43 & 25 & 36 & 45 & 280 & 28,0 \\
\hline PKM PONDOK RUMPUT & 500 & & 42 & 46 & 41 & 27 & & 68 & 12 & 21 & 10 & 0 & 0 & 267 & 53,4 \\
\hline PKM MERDEKA & 600 & & 39 & 20 & 9 & 0 & & 0 & 0 & 0 & 0 & 0 & 0 & 68 & 11,3 \\
\hline PKM TANAH SAREAL & 300 & & 0 & 8 & 14 & 8 & & 6 & 0 & 11 & 0 & 0 & 13 & 60 & 20,0 \\
\hline PKM SINDANG BARANG & 800 & & 41 & 60 & 48 & 89 & & 71 & 39 & 0 & 32 & 51 & 89 & 520 & 65,0 \\
\hline PKM KAYUMANIS & 800 & & 51 & 16 & 22 & 5 & & 19 & 24 & 8 & 14 & 0 & 10 & 169 & 21,1 \\
\hline PKM MEKARWANGI & 700 & & 14 & 16 & 14 & 20 & & 44 & 0 & 14 & 16 & 24 & 17 & 179 & 25,6 \\
\hline PKM KEDUNG BADAK & 1000 & & 86 & 68 & 57 & 48 & & 48 & 56 & 15 & 0 & 19 & 0 & 397 & 39,7 \\
\hline PKM BOGOR UTARA & 900 & & 54 & 61 & 88 & 9 & & 0 & 0 & 24 & 27 & 51 & 0 & 314 & 34,9 \\
\hline PKM WARUNG JAMBU & 1200 & & 46 & 100 & 55 & 43 & & 50 & 38 & 35 & 76 & 27 & 24 & 494 & 41,2 \\
\hline PKM TEGALGUNDIL & 1200 & & 10 & 29 & 0 & 27 & & 26 & 22 & 59 & 21 & 16 & 31 & 241 & 20,1 \\
\hline PKM BOGOR TIMUR & 1000 & & 56 & 118 & 92 & 54 & & 44 & 0 & 0 & 73 & 53 & 26 & 516 & 51,6 \\
\hline PKM BOGORSELATAN & 700 & & 0 & 212 & 258 & 0 & & 0 & 0 & 0 & 0 & 174 & 113 & 757 & \begin{tabular}{|l|}
708,1 \\
\end{tabular} \\
\hline PKM CIPAKU & 800 & & 0 & 0 & 21 & 9 & & 16 & 34 & 12 & 11 & 29 & 18 & 150 & 18,8 \\
\hline PKM MULYYAHARJA & 700 & & 0 & 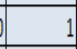 & 0 & 0 & & 7 & 22 & 11 & 74 & 40 & 13 & 168 & 24,0 \\
\hline PKM LAWANG GINTUNG & 800 & & 0 & 32 & 64 & 0 & & 70 & 62 & 0 & 21 & 25 & 4 & 278 & 34,8 \\
\hline PKM BONDONGAN & 1000 & & 0 & t & 0 & 0 & & 0 & 0 & 481 & 68 & 9 & 17 & 575 & 57,5 \\
\hline PKM BOGORTENGAH & 700 & & 20 & 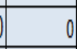 & 0 & 38 & & 0 & 32 & 0 & 0 & 0 & 45 & 135 & 19,3 \\
\hline PKM GANGAUT & 600 & & 29 & 18 & 25 & 8 & & 7 & 8 & 11 & 5 & 7 & 18 & 136 & 22,7 \\
\hline PKM SEMPUR & 400 & & 50 & 84 & 45 & 44 & & 71 & 60 & 69 & 0 & 24 & 9 & 456 & $6 \quad 114,0$ \\
\hline PKM BELONG & 600 & & 0 & 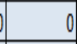 & 0 & 38 & & 33 & 29 & 25 & 17 & 5 & 8 & 155 & 25,8 \\
\hline PKM SEMPLAK & 700 & & 58 & 69 & 39 & 10 & & 37 & 18 & 18 & 10 & 10 & 55 & 324 & 46,3 \\
\hline PKM PASIRMULYA & 900 & & 51 & 56 & 46 & 39 & & 55 & 10 & 30 & 61 & 22 & 49 & 419 & 46,6 \\
\hline PKM PANCASAN & 800 & & 70 & 67 & 57 & 45 & & 45 & 30 & 85 & 112 & 52 & 0 & 563 & 70,4 \\
\hline PKM GANG KELOR & 900 & & 79 & 87 & 0 & 92 & & 56 & 48 & 49 & 35 & 22 & 16 & 484 & \begin{tabular}{|l|}
43,8 \\
\end{tabular} \\
\hline
\end{tabular}

Figure 1: Achievement of the City of Bogor Vaccination Program (Senior citizen) 


\begin{tabular}{|c|c|c|c|c|c|c|c|c|c|c|c|c|c|c|c|c|c|c|c|c|c|c|c|c|}
\hline \multirow{3}{*}{ NaMAFASYAVES } & \multicolumn{24}{|c|}{ SASSRAN PETUGSPVBDIK } \\
\hline & \multicolumn{2}{|r|}{3 HNar } & \multicolumn{2}{|r|}{ 311Mret } & \multicolumn{2}{|r|}{ OAppr } & \multicolumn{3}{|c|}{ BSApr } & NApp & \multicolumn{2}{|l|}{ 15.Apr } & \multicolumn{2}{|c|}{ O6-Apr } & \multicolumn{2}{|c|}{ OT-Apr } & \multicolumn{2}{|c|}{ QApr } & \multicolumn{2}{|r|}{ OAdpr } & \multicolumn{2}{|r|}{ 10-Apr } & \multicolumn{2}{|c|}{$\mid \begin{array}{c}\text { Pencopian Oosis } \\
1\end{array}$} \\
\hline & Dosis1 & Dosis2 & Dosis1 & 1 Dosis2 & oxist & 11 Dosis & Dosis & 1 Dosis & & & sis 1 Dos & & sis 10 & osis2 & Dosisi 10 & Dosis2 & Dosis1 & Dosis2 & Dosis1 & Dosis2 & Dosis 1 & Dosis2 & & Yh \\
\hline RSSALK & & & & 33 & & 86 & & & & & 84 & 32 & & & 54 & & 2121 & 19 & 9 & & & & & 746 \\
\hline RSPMI & & 0 & 0 & 34. & 0 & 35 & 0 & 0 & 0 & & 40. & 0 & 83 & 0 & 100 & & 066 & 6 & 0 & 0 & 0 & 3 & 361. & 1. 400 \\
\hline RSID & & 75 & 0 & 2. & 0 & 72 & 0 & 6 & & & 85 & 0 & 100 & 0 & 49 & & 080 & o & 04 & 43. & 0 & 9 & 577 & $7 \quad 6404$ \\
\hline RSIN & & 95 & 0 & 49 & 0 & 11 & 0 & 0 & & & 100 & 0 & 10. & 0 & 53 & & $0 \pi$ & 0 & 05 & 50 & 5 & 0 & 530 & 455 \\
\hline RSVANA & & 60 & 0 & 115 & 0 & 42 & 0 & 0 & 0 & & 0 & 0 & 0 & 0 & 0 & & & $0 \quad 0$ & 0 & $0 \quad$ & 0 & 0 & 207 & 7350 \\
\hline RSBSH & & 7 & 0 & 188 & 0 & 18.1 & 0 & 0 & & & 0 & 0 & 146 & 0 & 0 & & 076 & 60 & 0 & 0 & 0 & 0 & 5818 & 5806 \\
\hline RSBMC CAYAPRDA & & 68 & o & 93 & 0 & 68 & 0 & 0 & 0 & & 0 & 0 & 0 & 0 & 0 & & d & 0 & 0 & 0 & 0 & 0 & 229 & 368 \\
\hline RSSILAN & & 0 & 0 & 0 & 0 & 120 & 0 & 0 & d & & 111 & 0 & 0 & 0 & 120 & & 0 & $0 \quad 0$ & $0 \quad 18$ & 185 & 0 & 0 & 536 & 640 \\
\hline SSNENINA & & 81. & 0 & 0 & 0 & 9. & 0 & 73 & & & o & 0 & 45 & 1 & 0 & & 0 & 2. & $d$ & 0 & 0 & 39 & 331 & 148 \\
\hline 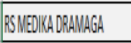 & & 0 & 0 & 97 & 0 & 0 & 0 & 0 & & & d & 0 & o & 1 & 134 & & 0 & $0 \quad 0$ & d & 0 & 0 & 0 & 231 & $67 x$ \\
\hline PSNULA & & 0 & 0 & 0 & 0 & 0 & 0 & 0 & 9 & & 107 & 0 & 0 & 1 & 0 & & 0 & $0 \quad 0$ & d & 0 & 0 & 0 & 107 & 758 \\
\hline SSLRPA & & 0 & d & 0 & 0 & 0 & 0 & 0 & 0 & & 89 & 1 & 97 & 1 & 78 & & d & 00 & 08 & 81. & 0 & 0 & 35 & $5 \quad 4554$ \\
\hline RSHERNA & & 0 & 0 & 0 & 0 & 103 & 0 & 0 & & & 0 & l & 184 & 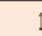 & 169 & & 0 & 00 & 0 & 6 & 0 & 6 & 488 & 435 \\
\hline RS SSAM BOOOR & & 11 & 0 & 43 & 0 & 37 & 0 & 0 & & & 59 & 0 & 142 & 1 & 110 & & $0 \quad 86$ & 60 & 0 & 0 & 0 & 0 & 488 & 500 \\
\hline RSUMNI & & 0 & 0 & 76 & 0 & 0 & 0 & 0 & 0 & & 0 & 0 & 4. & 1 & 4 & & 02 & 20 & 0 & 6 & 0 & 0 & & 188 \\
\hline
\end{tabular}

Figure 2: Achievements of the City of Bogor Vaccination Program (Public Servants)

The two pictures above explain that there are still obstacles related to the implementation of the Covid-19 vaccination program in the City of Bogor as evidenced by the target of the senior citizen who still has a small number of coming to the Puskesmas (local government clinic) to carry out vaccinations including targets for public servants such as RT, $\mathrm{RW}$ or cadres who have not all come to the hospital to do vaccinations.

The absence of good coordination and target mobilization with cross-sector is not optimal, including information and education about vaccines is still not optimal. There are several factors why the implementation of the vaccination program in the City of Bogor has not been maximized, such as the availability of human resources, management systems, and literacy about Covid-19.

This human resource is evidenced by the distribution of the schedule for health workers which is still insufficient when compared to the number of targets who come to the covid-19 vaccination service. There are still many health centers and hospitals that lack health personnel to serve this vaccination program.

In addition, the problem of the management system at both the hospital and the Puskesmas (government clinic) is considered to have not been optimal and is integrated with real data on vaccination recipients, so there is still maladministration at the RT or RW level. Management systems that are not yet optimal can also be seen from population data that are still not integrated with real data or facts in the field that deserve to receive vaccine priority. This phenomenon also occurs in several regions. 
The public literacy factor is also very influential with the covid-19 vaccination program. Many wild issues are circulating in the community that has not been properly managed so that they are getting wild and uncontrolled, such as the issue of illegal vaccines, the issue of vaccines with commercial purposes so that the main purpose of this vaccine does not work, also the issue of fake vaccines. Public literacy is still a major issue in several areas where this vaccination program is running. This challenge and resolution of public literacy certainly takes time and requires a good management process.

Along with the Covid-19 vaccine program, several policies and programs to support the successful implementation of the Covid-19 vaccine are being implemented by the City Government of Bogor. However, there are several problems in the implementation of the vaccine program so that the case of the positivity rate has yet to be stopped. In terms of literature, of course, there have been several studies that discuss the government vaccine program that is not only for Covid-19. Some of this literature can be used to parse and formulate problems in the implementation of the Covid-19 vaccine program as well as provide an overview of the solution based on literature studies.

Based on the description above, this study aims to describe the current conditions of the implementation of the Covid-19 vaccine program in the city of Bogor. In addition, this study will also analyze the existing obstacles so that they can get the right solution for the acceleration of this vaccine program.

In a study on the Covid-19 vaccination program using the PERT (Program Evaluation Technique) method, (Purwaningsih, Hayati, Surya, \& Mutiara, 2021) discussed the use of the PERT technique in implementing the COVID-19 Vaccination Program. PERT techniques can assist in answering the estimated time to complete the program, identify activities accompanied by start and finish times, the impact of delaying certain activities, what resources are needed at various points in time, revise and reschedule the program, and what additional resources are needed, etc. The results of the PERT analysis on the COVID-19 vaccination program in this study showed that the probability of the program being completed within 180 days was $48.57 \%$.

In a survey on the Covid-19 vaccine program in Indonesia, about 74 percent of respondents reported some knowledge about the Indonesian Government's intention to distribute the COVID-19 vaccine in the country. The percentages vary between provinces. Approximately 61 percent of respondents in Aceh reported on the knowledge of the Indonesian Government's intentions regarding the distribution of the COVID-19 vaccine, while in several provinces in Sumatra, Sulawesi and Sulawesi, Java Islands, 65-70 percent of respondents were familiar with 
similar information. The provinces of Java, Maluku, the Kalimantan Islands, as well as Papua, and several other provinces, reported higher levels of information (above 70 percent). This survey does not explore the reasons for these variations and further studies are needed to understand these factors (Kementerian Kesehatan Republik Indonesia dan WHO, 2020).

Regarding the study that discussed the Covid-19 Vaccine acceptance survey, (Kementerian Kesehatan Republik Indonesia, ITAGI, WHO, \& UNICEF, 2020) concluded that like other countries around the world, the COVID-19 outbreak was first announced in March 2020 and being prolonged has a significant impact on the health sector and the Indonesian economy. Indonesia has made every effort to overcome the existing challenges.

Meanwhile, related to the public response to the vaccination program, it was discussed by (Rachman \& Pramana, 2020) who analyzed the public's response to the vaccination discourse by classifying these responses into positive and negative responses. The results of the analysis show that public responses are more positive towards discourse $(30 \%)$ than negative responses (26\%). The words that appear most frequently also indicate that there are more words with positive sentiment than words with negative sentiment. The LDA model that was built can also capture topics discussed by the community regarding vaccination discourse, such as public talk about vaccine controversies that are considered hasty, certification of halal vaccine, and public doubts about the quality of the vaccine to be used.

The Covid-19 vaccination program requires a public education process so that proper knowledge is realized and the vaccination program runs well. Social media such as Instagram is a vaccine education media that can be accessed in a pandemic that limits mobility. The Instagram account @indonesiavoice _ is an option that provides educational information regarding Covid-19 vaccination in Indonesia. Like a study made by (Letuna, 2021) who saw how Instagram became an educational medium for Covid-19 vaccination in Indonesia. The method used in this study is a qualitative content analysis method with an inductive approach where the data compression procedure is carried out from complex texts and the process of constructing meaning from the data through themes or categories that appear in the study. The results of this study indicate that user preferences or account followers tend to lead to posts that use self-portraits, infographics, and activities about the Covid-19 vaccination process in Indonesia.

Regarding the legal aspect, the implementation of the Covid-19 vaccine procurement in the context of the vaccination program shows that the implementation of procurement for emergency handling requires a special mechanism which is carried out through simplification of 
administrative processes and by the regulations for the procurement of goods/services in emergency handling. Article 27 paragraph (2) and paragraph (3) of the Covid-19 Handling Law which has legal impunity which does not necessarily eliminate the responsibility of the procurement actors, but the procurement actors are still subject to legal accountability based on parameters of good faith and implementation by laws and regulations (Mufidah \& Tejomurti, 2021)

The government's efforts to implement the Covid-19 Vaccination program are not easy. This is evidenced by the emergence of hoax news in various media. Therefore, (Nani Rahayu, 2021) made this study to find out hoax news about the Covid 19 vaccine regarding 1) Hoax about the composition of the Covid 19 vaccine; 2) Hoax about the impact of the Covid 19 vaccine; 3) Hoaxes about the rejection of the Covid 19 vaccine. The results showed hoax news about the Covid 19 vaccine related to its composition, that the Covid 19 vaccine contains dangerous ingredients including borax, formalin, Vero cells, and some even said the vaccine was made from a male fetus. Hoaxes about the side effects include death, infertility, enlargement of the male genitalia, and modification of human DNA. Hoax for vaccine rejection is the unavailability of the Indonesian Doctors Association as a medical organization that is not willing to be vaccinated for the first time. It was concluded that there was hoax news about the Covid 19 vaccine circulating in Indonesia from November 2020 to January 2021.

Meanwhile, the Covid-19 vaccine program in the United States requires a national strategy for the promotion of the COVID-19 vaccine that combines the urgency and commitment of Operation Warp Speed with innovative behavioral science and social marketing approaches to increase trust and acceptance of the COVID-19 vaccine in a diverse population. There needs to be cooperation and good behavior towards this program to achieve a successful national COVID-19 vaccine program (Volpp, Loewenstein, \& Buttenheim, 2021).

In Europe, the EAHP (European Association of Hospital Pharmacies) provides its views regarding the Covid-19 Vaccine program. They assume that the national vaccination program must take into account local storage conditions to ensure the smooth launch of vaccination activities across the health sector. Not all hospital pharmacies, especially those operating in small hospitals, are equipped with refrigeration facilities that can meet the conditions required for some vaccines under development. But even those with these facilities may not be able to cope with the amount of storage needed to support mass vaccination of the population against COVID-19 (Volpp et al., 2021). 


\section{METHODS}

Qualitative research is a type of social science research that collects and works with non-numerical data and seeks to explain the meaning of the data to help understand social life through the study of targeted populations or places.

In sociology, qualitative research usually focuses on the micro-level of social interactions that shape everyday life, whereas quantitative research usually focuses on trends and phenomena at the macro level (Maxwell \& Reybold, 2015). Reveal that qualitative research is characterized by methods that are inductive and open. Qualitative research is an important and accepted approach in the social sciences. The four specific features of qualitative research namely "understanding the meaning of the research, investigating the influence of the specific context in which the individual and the activity under study is located, explaining the process by which these meanings and contexts lead to certain features or outcomes, and explicitly incorporating the researcher's subjectivity" are central to the research. qualitative. These features form specific methods, analytical strategies, and approaches to validity and generalization that give qualitative research unique value to social research.

According to (Rahardjo, 2017) there are at least eight types of qualitative research, namely ethnography, case studies, document studies, natural observation, focused interviews, and phenomenology. phenomenology), grounded theory, and historical studies (historical research).

a. Qualitative research methods usually collect data when in the field, where researchers have issues and problems. This real data rarely take the researcher out of the geographic location of the study to collect information or data.

b. Qualitative researchers usually collect various forms of data, such as interviews, observations, and documents, rather than relying on a single data source.

c. This type of research method works to solve complex problems by breaking them down into meaningful conclusions, which are easy for everyone to read and understand.

Based on the information above and considering the objectives of this study, this study will use a qualitative study with a document studies approach. A document or text study is a study that focuses on the analysis or interpretation of written material. This written material can be sourced from textbooks, magazines, notes, manuscripts, articles, and the like. A study with this approach must obtain and dig up the widest possible information to obtain a detailed and comprehensive picture, especially from published texts or documents. Therefore, this approach 
E-ISSN: 2808-5361

http://e-journal.fkmumj.ac.id/
Proceeding The First

Muhammadiyah

Internasional- Public Health

and Medicine Conference

is used to be able to focus on the analysis or interpretation of written material based on its context.

This study uses data that is readily available in the form of publications such as scientific papers published by indexed journals related to this field of study. Other publications include books, lecture materials, and other notes. Usually, this type of data is called secondary data or data obtained not directly from the source.

\section{RESULTS AND DISCUSSIONS}

The following describes the updated data related to the Covid-19 vaccination program organized by all hospitals in the city of Bogor as follows:

\section{Table 1: Covid-19 Vaccination Program by Hospitals in Bogor City}

\section{VACCINATION PROGRAM BY HOSPITAL IN BOGOR}

CITY AS OF 14-20 JANUARY 2021

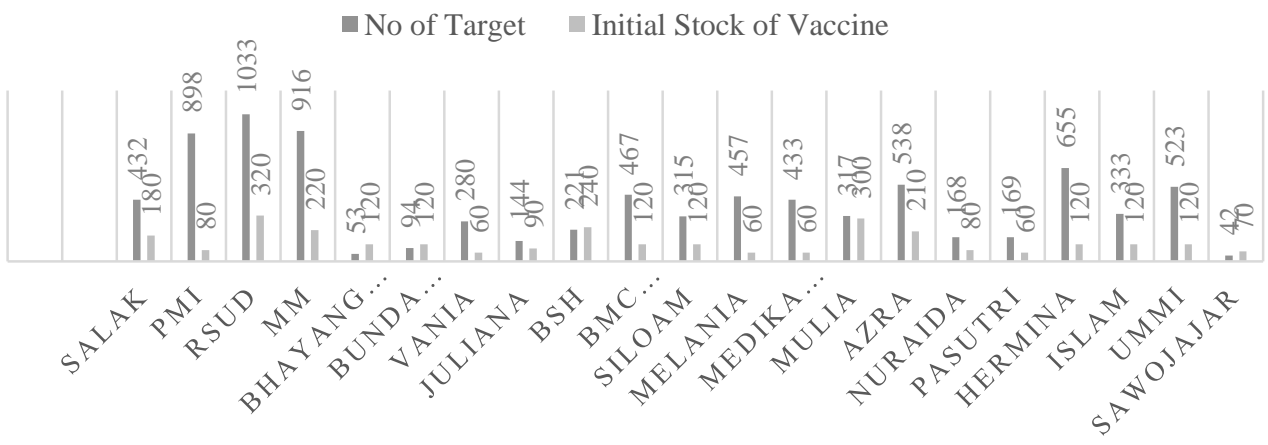

Source: Health Department of Bogor City Government, 2021

The table above shows that the total available vaccines are 2,870 while the target is 8,488. The Local Government of Bogor City Hospital has the highest target of 1,033 people while the available vaccines are only 320 . Although it is the largest number is in terms of the number of vaccine stocks and target people, but this fact is still far from what was expected. Meanwhile, the Sawojajar hospital has a target people of only 45 but has more than 70 vaccine stock. This indicates that the availability of vaccine stock with the target number is not balanced so that the vaccination program by the hospitals in the city of Bogor is still not optimal.

The implementation of the Covid-19 vaccination program in Bogor City which is organized by all hospitals has yet to have a positive impact on the success of this program. From 
the available data, it turns out that there are still many target people who did not attend the vaccination program. This is evidenced by the data that only 1,452 target people have been injected from the initial target of 1,695. The following table describes the overall implementation of the Covid-19 vaccination program in the city of Bogor that is held in hospitals.

\section{Table 2: Implementation of the Bogor City Covid-19 Vaccination Program}

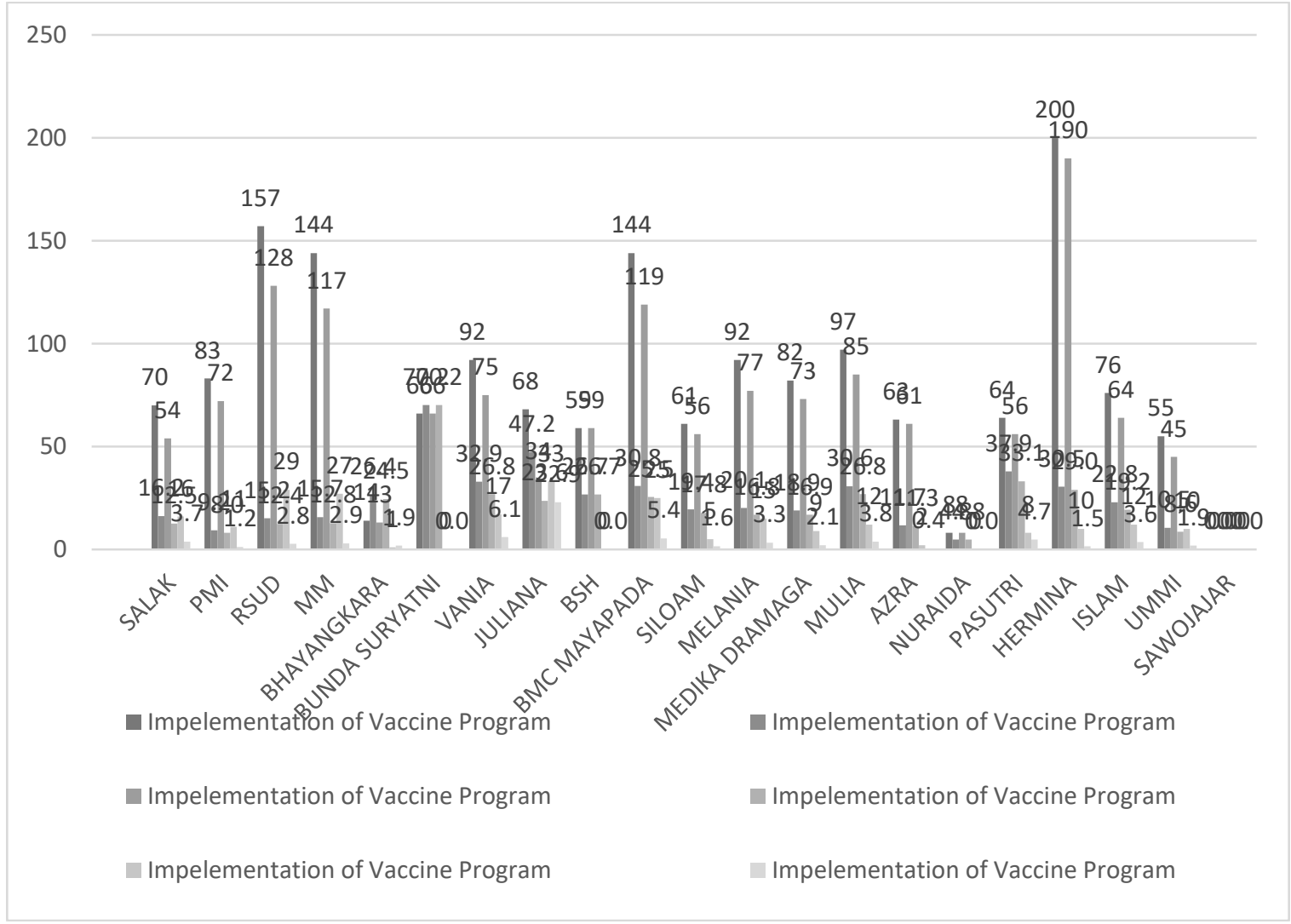

The implementation of the Covid-19 vaccination program at the Puskesmas (local government clinic) is certainly different from that at the hospital. From the available data, the target population for vaccines is 998 people while the available vaccines are 1,890. This means that there is an excess of around 1,000 doses of vaccine provided for all Puskesmas in Bogor city. The table below illustrates that the Puskesmas Sindang Barang has the maximum target number of people, namely 60 people, while the available vaccine is only 40 doses. This is inversely proportional to the North Bogor Puskesmas which has a target of 47 people while the total stock of vaccines is 120 doses. Likewise, the Puskesmas Sempur where the target person is 
only 35 while the total vaccine stock is 180 doses. Thus, the implementation of this vaccine program is not by valid data and does not match the target person and the number of vaccine stocks.

Table 3: Vaccination Program Held by Puskesmas (Local Government Clinic) in Bogor City

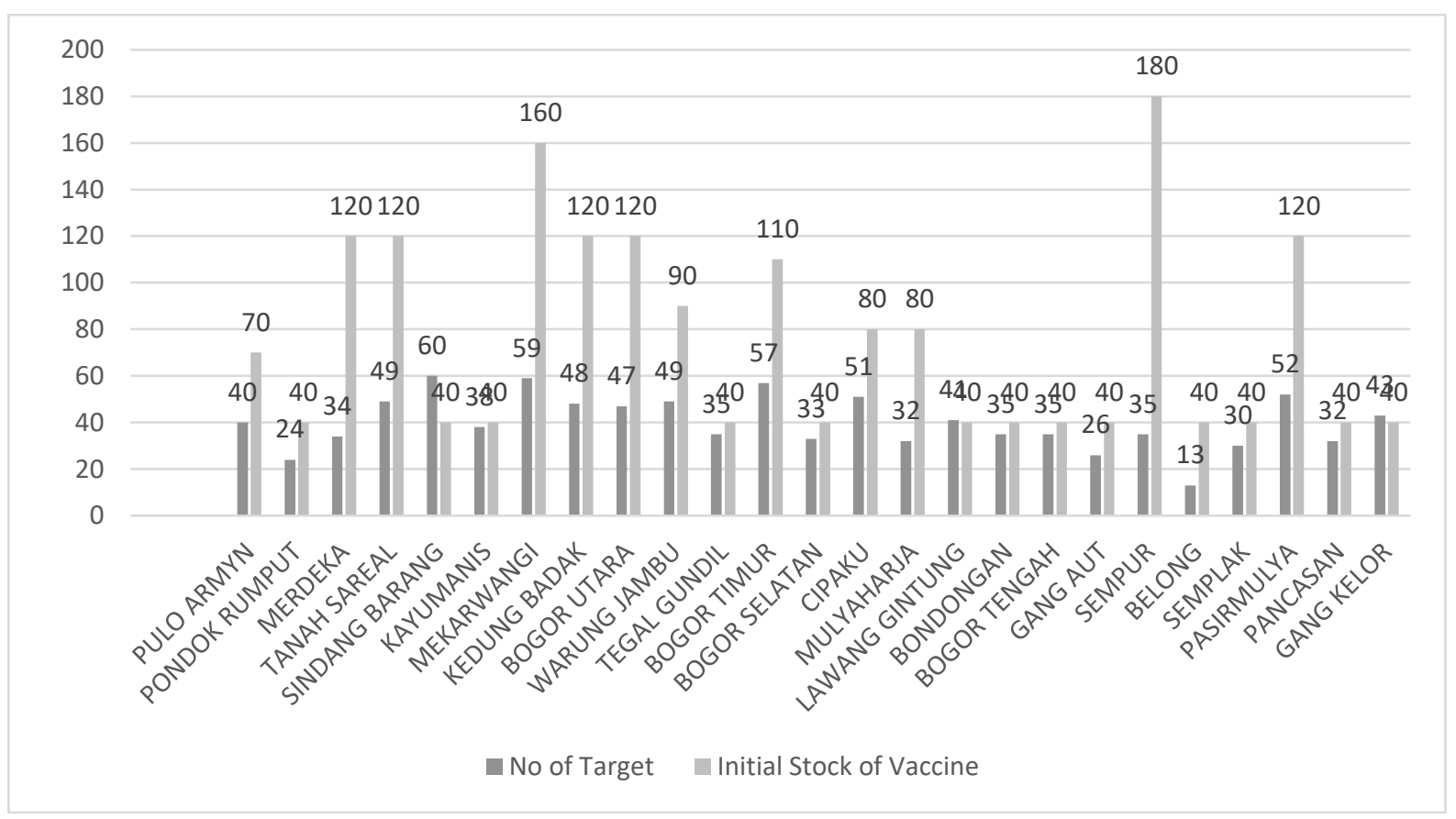

\section{CONCLUSION DAN SUGGESTION}

After getting a real picture of the data on the Covid-19 vaccination program in the city of Bogor, both carried out by hospitals and Puskesmas, the core problem is the accuracy of the data. The data do not match the requirements for people to be vaccinated. The data between target people and the number of vaccine stocks are also not the same. In addition, public literacy also contributes to this vaccination program where the level of attendance of people to hospitals and Puskesmas is still far from expectations. In addition, the availability of medical personnel to carry out this program is also an obstacle so that the Covid-19 vaccination program in the city of Bogor has not materialized as expected.

\section{REFERENCES}

Kementerian Kesehatan Republik Indonesia dan WHO. (2020). COVID-19 Vaccine Acceptance Survey in Indonesia. Journal of Materials Processing Technology, 1(1). 
Kementerian Kesehatan Republik Indonesia, ITAGI, WHO, \& UNICEF. (2020). Survei Penerimaan Vaksin COVID-19 di Indonesia. Satuan Gugus Tugas Penanganan COVID19, (November).

Letuna, M. A. N. (2021). Instragram Sebagai Media Edukasi Vaksin Covid-19 Di Indonesia. Jurnal Communio: Jurnal Ilmu Komunikasi, 10(1).

Maxwell, J. A., \& Reybold, L. E. (2015). Qualitative Research. In International Encyclopedia of the Social \& Behavioral Sciences: Second Edition. https://doi.org/10.1016/B978-0-08097086-8.10558-6

Mufidah, L., \& Tejomurti, K. (2021). ANALISIS YURIDIS PELAKSANAAN PENGADAAN VAKSIN DALAM PENANGANAN CORONAVIRUS DISEASE 2019 (COVID-19) [A Legal Analysis of the Implementation of Vaccine Procurement in Managing the Coronavirus Disease 19 (Covid-19)]. Law Review. https://doi.org/10.19166/lr.v0i0.3109

Nani Rahayu, R. (2021). VAKSIN COVID 19 DI INDONESIA: ANALISIS BERITA HOAX. JURNAL EKONOMI, SOSIAL \& HUMANIORA (Vol. 2).

Purwaningsih, A., Hayati, A. M., Surya, N. F., \& Mutiara, Y. O. (2021). Penyusunan Proposal dan Penerapan Program Evaluation Review Technique (PERT) dalam Program Vaksinasi Covid-19. Jurnal Perencanaan, Pemantauan, Dan Penilaian Program.

Rachman, F. F., \& Pramana, S. (2020). Analisis Sentimen Pro dan Kontra Masyarakat Indonesia tentang Vaksin COVID-19 pada Media Sosial Twitter. Health Information Management Journal ISSN, 8(2).

Rahardjo, M. (2017). STUDI KASUS DALAM PENELITIAN KUALITATIF: KONSEP DAN PROSEDURNYA. ABA Journal. https://doi.org/10.1002/ejsp.2570

Volpp, K. G., Loewenstein, G., \& Buttenheim, A. M. (2021). Behaviorally Informed Strategies for a National COVID-19 Vaccine Promotion Program. JAMA - Journal of the American Medical Association. https://doi.org/10.1001/jama.2020.24036 